\title{
Urgensi Regulasi Eksekusi Pidana Denda di Bidang Perpajakan Pasca Undang-Undang Cipta Kerja
}

\author{
Arief Sultony \\ Pusat Pendidikan dan Pelatihan Pajak, Badan Pendidikan dan Pelatihan Keuangan, Kementerian Keuangan. \\ J1. Sakti Raya No. 1, Kemanggisan, Jakarta Barat-11480. \\ Correspondence email: sultony86.ac@gmail.com
}

\begin{abstract}
Abstrak.UU Cipta Kerja telah menghapus Pasal 13 ayat (5) dan Pasal 15 ayat (4) UU UU KUP. Penghapusan pasal-pasal tersebut dikhawatirkan akan menghilangkan pemulihan kerugian keuangan negara di bidang perpajakan. Tujuan penelitian ini adalah untuk mengetahui bagaimana regulasi eksekusi pidana denda perpajakan untuk menjamin terpulihkannya kerugian keuangan negara sebelum disahkannya UU Cipta Kerja dan apa akibat diberlakukan UU Cipta Kerja terhadap pemulihan kerugian keuangan negara yang disebabkan oleh tindak pidana perpajakan. Penelitian menggunakan metode penelitian hukum normatif untuk mencari pemecahan masalah. Dari hasil penelitian diketahui bahwa UU KUP tidak mengatur eksekusi pidana denda secara khusus sehingga terdapat kemungkinan pidana denda tidak terbayar. Akan tetapi, berdasarkan Pasal 13 ayat (5) dan Pasal 15 ayat (4) UU KUP, pemulihan kerugian keuangan negara tetap dapat dilakukan melalui penetapan pajak setelah putusan pidana inkrah. Penghapusan pasal-pasal tersebut oleh UU Cipta kerja berisiko tidak terpulihkannya kerugian negara. Untuk mengatasi permasalahan, dibutuhkan segera regulasi eksekusi pidana denda perpajakan yang dapat memulihkan kerugian keuangan negara.
\end{abstract}

Kata Kunci: pidana denda perpajakan; UU Cipta Kerja; pemulihan kerugian keuangan negara

Abstract. Job Creation Law has removed Article 13 paragraph (5) and Article 15 paragraph (4) of General Provision and Tax Procedures (KUP) Law. The absence of these articles may result in state financial loss recovery in taxation cannot be recovered. This research will identify how the regulation on the execution of tax fines related to the recovery of state financial loss before Job Creation Law was enacted and the consequences of Job Creation Law implementation on state financial losses recovery caused by tax crime. By applying the normative legal method, this research will propose the solution to the problem. The findings indicate that the KUP Law does not specifically regulate the execution of fines, so that there is a possibility that the fines will not be paid. However, based on Article 13 paragraph (5) and Article 15 paragraph (4) of the KUP Law, the state financial loss recovery can be imposed through tax assessment after court decision has permanent legal force. The elimination of these articles by Job Creation Law has the risk that the state financial losses cannot be recovered. Therefore, regulation in tax criminal fines execution is urgently required so that state financial losses can be recovered.

Keywords: tax criminal fines; job creation law; state financial losses recovery

\section{PENDAHULUAN}

Kebijakan APBN yang mandiri terlihat dari kontribusi dominan penerimaan perpajakan terhadap pendapatan negara. Dalam lima tahun terakhir kontribusi penerimaan perpajakan melebihi 82\%. ${ }^{1}$ Dengan kemandirian APBN yang mengandalkan penerimaan pajak, diharapkan mengurangi kebutuhan pembiayaan yang bersumber dari utang. Untuk dapat tercapainya penerimaan pajak diharapkan adanya kepatuhan sukarela dari Wajib Pajak dan untuk menciptakan kepatuhan maka diperlukan penegakan hukum. Untuk itulah Undang-Undang Nomor 6 tahun 1983 tentang Ketentuan Umum Dan Tata Cara Perpajakan Sebagaimana Telah Beberapa Kali Diubah Terakhir Dengan Undang-Undang Nomor 16 tahun 2009 (UU KUP) dilengkapi dengan ketentuan penegakan hukum.

Dalam UU KUP terdapat dua jenis penegakan hukum, yaitu: penegakan hukum administrasi dan penegakan hukum pidana.. Penegakan hukum administrasi dilakukan dengan pemeriksaan untuk menguji apakah Wajib Pajak telah menjalankan kepatuhan suka relanya sesuai peraturan perundang-undangan perpajakan. Pelanggaran terhadap kewajiban administrasi dikenai sanksi administrasi berupa denda, bunga atau kenaikan. Penegakan hukum pidana di bidang perpajakan dilakukan apabila Direktur Jenderal (Dirjen) Pajak memperoleh atau menerima informasi, data, laporan, dan pengaduan yang mengandung dugaan telah terjadi tindak pidana di bidang perpajakan atau terjadi tindak pidana di bidang perpajakan yang diketahui seketika pada saat sedang berlangsung atau baru saja terjadi. ${ }^{2}$ Pelanggaran pidana di bidang perpajakan dikenai sanksi pidana.

Menurut Gunadi, salah satu maksud dari dilengkapinya UU KUP dengan ketentuan/sanksi pidana adalah untuk menciptakan efek pencegahan, pemberantasan dan penjeraan para penghindar pajak. ${ }^{3}$ Dalam UU KUP, pengenaan

\footnotetext{
${ }^{1}$ Informasi APBN dapat dilihat pada web site Kementerian Keuangan RI, https: //www.kemenkeu.go.id/dataapbn.

${ }^{2}$ Lihat Pasal 43A UU KUP Jo. Pasal 2 dan Pasal 35 Peraturan Menteri Keuangan Nomor 239/PMK.03/2014

${ }^{3}$ Gunadi, Panduan Komprehensif Ketentuan Umum Perpajakan (KUP), Edisi Revisi, (Jakarta:Bee Media Indonesia, 2016),
} hlm. 549 
sanksi pidana tidak sekedar dimaksudkan untuk menjatuhkan penderitaan (retributive) bagi pelakunya, tetapi juga mengupayakan pemulihan kerugian keuangan negara yang timbul dari tindak pidana di bidang perpajakan. Hal ini dapat dilihat dari model pengaturan sanksi pidana di bidang perpajakan. Untuk delik alpa (culpa) Pasal 38 menggunakan stelsel alternatif antara sanksi kurungan dan pidana denda. Untuk delik sengaja (dolus/opzet) Pasal 39 dan 39A menggunakan stelsel komulatif sanksi pidana penjara dan pidana denda.

Penggunaan pidana denda mengisyaratkan adanya tujuan pemulihan kerugian keuangan negara (recovery asset) dalam pemidanaan di bidang perpajakan. Tujuan pemulihan kerugian negara menjadi wajar karena fungsi utama pajak adalah mengumpulkan dana untuk kas negara. Namun demikian pemulihan kerugian negara tidak selalu berhasil dilakukan dengan instrument pidana denda. Putusan Hakim pidana tidak selalu menjamin pidana denda dibayar oleh terpidana. Keadaan ini diduga karena UU KUP tidak mengatur norma pelaksanaan pidana denda secara khusus sehingga terjadi inkonsistensi diantara putusan-putusan Hakim yang dapat berakibat tidak terbayarnya pidana denda.

Para penyusun UU KUP sepertinya telah menyadari risiko kemungkinan tidak terbayarnya pidana denda. UU KUP mengatur bahwa sanksi pidana tidak menghilangkan utang pajak. Pasal 13 ayat (5) dan Pasal 15 ayat (4) mengatur bahwa utang pajak tetap ditagih setelah putusan pidana mempunyai kekuatan hukum tetap (incraht). Ketentuan-ketentuan tersebut memberikan pemahaman bahwa UU KUP tetap menginginkan adanya pemulihan kerugian negara walaupun telah dilakukan penegakan hukum pidana di bidang perpajakan.

Omnibus law Rancangan Undang-Undang Cipta Kerja telah secara resmi diundangkan sebagai Undang-Undang Nomor 11 Tahun 2020 tentang Cipta Kerja (UU Cipta Kerja) pada tanggal 2 November 2020. UU Cipta Kerja juga menyentuh perubahan undang-undang pada sektor perpajakan yang dituangkan pada Bab VI tentang Kemudahan Berusaha, Bagian Ketujuh tentang Perpajakan. UU Cipta Kerja menghilangkan kewenangan Dirjen Pajak untuk menetapkan dan menagih utang pajak akibat dilakukannya perbuatan pidana di bidang perpajakan dengan menghapus ketentuan pada Pasal 13 (5) dan Pasal 15 ayat (4) UU KUP. ${ }^{4}$

Penghapusan Pasal 13 (5) dan Pasal 15 ayat (4) UU KUP oleh UU Cipta kerja menciptakan polemik diantara para penegak hukum, khususnya penegak hukum pidana di bidang perpajakan. Penghapusan tersebut dikawatirkan dapat berisiko tidak terpulihkannya kerugian keuangan negara yang timbul dari perbuatan pidana di bidang perpajakan. Untuk itu, penelitian ini merumuskan masalah: bagaimana regulasi eksekusi pidana denda perpajakan untuk menjamin terpulihkannya kerugian keuangan negara sebelum disahkannya UU Cipta Kerja dan apa akibat diberlakukan UU Cipta Kerja terhadap pemulihan kerugian keuangan negara yang disebabkan oleh tindak pidana perpajakan Setelah mengetahui jawaban dalam masalah yang telah dirumuskan, penelitian ini mencoba mencari solusi mengenai bagaimana konsep eksekusi pidana denda di bidang perpajakan yang dapat menjamin terpulihkannya kerugian keuangan negara di bidang perpajakan.

\section{METODE}

Metode penelitian ini menggunakan penelitian hukum normatif. Data yang digunakan adalah data sekunder yang terdiri dari bahan hukum primer, sekunder dan tersier yang dikumpulkan melalui studi Pustaka dan dianalisis secara kulitatif.

Bahan hukum yang diperoleh berupa teori hukum, asas hukum, peraturan perundang-undamgan dan pendapat ahli digunakan untuk menganalisis regulasi eksekusi pidana denda di bidang perpajakan serta konsekwensinya terhadap pemulihan kerugian keuangan negara, baik sebelum maupun setelah diberlakukan UU Cipta Kerja. Dari analisis tersebut akan diperoleh apakah diperlukan segera (urgen) untuk menyusun regulasi eksekusi pidana denda di bidang perpajakan pasca Undang-Undang Cipta Kerja, Selanjutnya penelitian ini menawarkan solusi bentuk regulasi dan konsep formulasi eksekusi pidana denda di bidang perpajakan yang dapat menjamin pemulihan kerugian keuangan negara.

\section{HASIL DAN PEMBAHASAN}

\section{Norma Eksekusi Pidana Denda di Bidang Perpajakan}

Jenis sanksi pidana yang diterapkan dalam UU KUP terdiri dari sanksi pidana pokok kurungan, penjara dan denda yang dikenakan secara stelsel alternatif maupun stelsel komulatif dengan pola pemidanaan minimum dan maksimum khusus. Stelsel alternatif terdapat dalam rumusan delik alpa (culva) Pasal 38 UU KUP dimana pidana kurungan dialternatifkan dengan pidana denda dan menggunakan pola minimum dan maksimum khusus sebagi berikut:

Setiap orang yang karena kealpaannya: [...] didenda paling sedikit 1 (satu) kali jumlah pajak terutang yang tidak atau kurang dibayar dan paling banyak 2 (dua) kali jumlah pajak terutang yang tidak atau kurang dibayar, atau dipidana kurungan paling singkat 3 (tiga) bulan atau paling lama 1 (satu) tahun.

${ }^{4}$ Lihat Pasal 113 Undang-Undang Nomor 11 Tahun 2020 tentang Cipta Kerja. 
Sedangkan untuk delik sengaja (opzet/dolus) dan percobaan dipidana dengan pidana penjara dan denda yang diterapkan secara komulatif dengan pola minimum dan maksimum khusus sebagai berikut:

Pasal 39 (1):

Setiap orang yang dengan sengaja: [...] dipidana dengan pidana penjara paling singkat 6 (enam) bulan dan paling lama 6 (enam) tahun dan denda paling sedikit 2 (dua) kali jumlah pajak terutang yang tidak atau kurang dibayar dan paling banyak 4 (empat) kali jumlah pajak terutang yang tidak atau kurang dibayar.

\section{Pasal 39A}

Setiap orang yang dengan sengaja: [...] dipidana dengan pidana penjara paling singkat 2 (dua) tahun dan paling lama 6 (enam) tahun serta denda paling sedikit 2 (dua) kali jumlah pajak dalam faktur pajak, bukti pemungutan pajak, bukti pemotongan pajak, dan/atau bukti setoran pajak dan paling banyak 6 (enam) kali jumlah pajak dalam faktur pajak, bukti pemungutan pajak, bukti pemotongan pajak, dan/atau bukti setoran pajak.

\section{Pasal 39 ayat (3):}

Setiap orang yang melakukan percobaan untuk melakukan tindak pidana [...] dipidana dengan pidana penjara paling singkat 6 (enam) bulan dan paling lama 2 (dua) tahun dan denda paling sedikit 2 (dua) kali jumlah restitusi yang dimohonkan dan/atau kompensasi atau pengkreditan yang dilakukan dan paling banyak 4 (empat) kali jumlah restitusi yang dimohonkan dan/ atau kompensasi atau pengkreditan yang dilakukan.

Rumusan pemidanaan di atas membawa konsekuensi penuntut umum harus menuntut terdakwa dengan pidana penjara dan denda secara komulatif dalam delik kesengajaan dan percobaan. Begitu juga halnya dengan Hakim dalam putusannya, dalam hal terdakwa terbukti bersalah maka harus menjatuhkan hukuman dengan pidana penjara dan pidana denda secara komulatif. Pola pemidanaan tersebut sepertinya telah memenuhi tujuan integratif dalam arti mengintegrasikan beberapa fungsi sekaligus retribution yang bersifat utilitarian, dimana pencegahan dan sekaligus rehabilitasi yang kesemuanya dilihat sebagai sasaran yang harus dicapai oleh suatu rencana pemidanaan. ${ }^{5}$

Namun demikian, legislator tidak memperhitungkan bagaimana proses eksekusi terhadap pidana denda di bidang perpajakan. UU KUP tidak memuat norma eksekusi atau pelaksanaan pidana denda. UU KUP tidak mengatur secara khusus batas waktu kapan pidana denda harus dibayar oleh terpidana, tindakan yang dapat memaksa terpidana membayar dendanya seperti penyitaan dan pelangan harta, dan hukuman alternatif apabila pidana denda tidak terbayar. Ketiadaan norma tersebut dapat menimbulkan permasalahan dalam pelaksanaan eksekusi pidana denda.

Bagir Manan menjelaskan bahwa semua kaidah umum berlaku dan prevail kecuali secara khusus diatur berbeda. ${ }^{6}$ Dengan kata lain ketentuan-ketentuan yang didapati dalam aturan hukum umum tetap berlaku kecuali yang diatur khusus dalam aturan hukum khusus tersebut. Selanjutnya Andi Hamzah menggarisbawahi hal terpenting untuk diperhatikan, yaitu penyimpangan-penyimpangan dalam undang-undang atau peraturan-peraturan khusus tersebut terhadap ketentuan umum KUHP. Selebihnya, yang tidak menyimpang dengan sendirinya tetap berlaku ketentuan umum KUHP, berdasarkan asas lex specialis derogate legi generali. Jadi selama tidak ada ketentuan khusus berlakulah ketentuan umum itu. ${ }^{7}$ Dari pendapat-pendapat tersebut dapat disimpulkan bahwa walaupun pidana pajak merupakan hukum pidana khusus, namun jika UU KUP tidak mengatur secara khusus maka tunduk kepada hukum generalienya yaitu KUHP untuk materiel dan KUHAP untuk hukum acaranya. Oleh karenanya, bila denda tidak dibayar maka berlakulah ketentuan yang diatur dalam KUHP dan KUHAP.

Pasal 273 ayat (1) dan ayat (2) KUHAP mengatur batas waktu pembayaran pidana denda yaitu satu bulan dan dapat diperpanjang paling lama satu bulan. Kemudian mengenai perampasan dan pelelangan barang bukti diatur pada ayat (3) sebagai berikut: "Jika putusan pengadilan juga menetapkan bahwa barang bukti dirampas untuk negara, selain pengecualian sebagaimana tersebut pada Pasal 46, jaksa menguasakan benda tersebut kepada kantor lelang negara dan dalam waktu tiga bulan untuk dijual lelang, yang hasilnya dimasukkan ke kas negara untuk dan atas nama jaksa." Dari ketentuan tersebut dapat diketahui bahwa pelaksanaan pembayaran pidana denda di bidang perpajakan dilakukan dalam jangka waktu satu bulan dapat diperpanjang paling lambat dua bulan sejak putusan. Perampasan dan pelelangan barang bukti untuk pembayaran denda hanya bisa dilakukan jika putusan pengadilan menetapkan bahwa barang bukti dirampas untuk negara.

Bagaimana jika putusan pengadilan tidak menetapkan harta terdakwa dirampas untuk negara? Pasal 30 KUHP mengatur apabila pidana denda tidak dibayar diganti dengan pidana kurungan paling sedikit satu hari dan paling lama enam bulan kecuali ada pemberatan pidana denda disebabkan karena perbarengan atau pengulangan, atau karena ketentuan Pasal 52 maka pidana kurungan pengganti paling lama delapan bulan. Sistem pelaksanaan pidana denda

\footnotetext{
${ }^{5}$ Muladi, 2002, Lembaga Pidana Bersyarat, (Bandung:Penerbit Alumni), hlm. 49-51.

${ }^{6}$ Bagir Manan, Sistem Peradilan Berwibawa Suatu Pencarian, (Yogyakarta:FH UII Press, 2005), hlm. 89-90

${ }^{7}$ Andi Hamzah, 2010, Asas-Asas Hukum Pidana, (Jakarta:Rineka Cipta, 2010), hlm. 12.
} 
yang diatur dalam KUHAP dan KUHP tersebut akan meberikan konsekwensi pelaksanaan pidana denda di bidang perpajakan yang akan diuraikan di bawah ini.

Model pemidanaan pada Pasal 38 adalah stelsel alternatif kurungan dan denda, konsekwensinya Hakim akan memilih menjatuhkan pidana kurungan atau denda. Contoh, terdakwa diputus bersalah dengan kerugian pajak yang tidak disetor sebesar 10 milyar rupiah. Keadaan ini dapat memunculkan beberapa kemungkinan pola putusan Hakim. Pertama, Hakim menjatuhkan pidana kurungan selama antara tiga bulan sampai dengan satu tahun. Kedua, Hakim menjatuhkan pidana denda sebesar antara 10 milyar rupiah sampai dengan 20 milyar rupiah tanpa penetapan perampasan harta terdakwa. Ketiga, Hakim menjatuhkan pidana denda sebesar antara 10 milyar rupiah sampai dengan 20 milyar rupiah dengan penetapan perampasan harta terdakwa.

Konsekwensi pada pola putusan pertama adalah pidana hanya bersifat retributif dengan memberikan pembalasan atas kesalahan yang telah dilakukan berupa kurungan badan. Pada pola putusan kedua, pemidanaan bersifat utilitarian dengan memberikan manfaat pada penerimaan kas negara. Namun demikian, pada putusan pola kedua dapat memberikan konsekwensi bahwa pidana denda tidak dibayar. Apabila pidana denda tidak dibayar maka berlakulah ketentuan pada Pasal 30 KUHP yaitu pidana denda diganti dengan pidana kurungan paling sedikit satu hari dan paling lama enam bulan atau jika ada pemberatan paling lama delapan bulan. Akibat dari subsider tersebut, pemidanaan kehilangan sifat kemanfaatan berupa penerimaan pada kas negara. Pola putusan ketiga lebih menjamin tujuan kemanfaatan hukum berupa penerimaan pada kas negara karena harta terpidana telah dirampas terlebih dahulu dan apabila pidana denda tidak dibayar dilakukan pelelangan.

Berbeda dengan Pasal 38, model pemidanaan pada Pasal 39 ayat (1), ayat (2) dan Pasal 39A UU KUP menggunakan stelsel komulatif pidana penjara dan denda sehingga konsekwensinya Hakim akan menjatuhkan pidana penjara ditambah denda. Contoh, dalam perbuatan pidana Pasal 39 ayat (1) UU KUP, terdakwa diputus bersalah dengan kerugian pajak yang tidak disetor sebesar 10 milyar rupiah. Dari putusan tersebut akan terdapat kemungkinan pola pemidanaan sebagai berikut.

Pertama, Hakim menjatuhkan pidana penjara selama antara enam bulan sampai dengan enam tahun ditambah pidana denda sebesar antara $\mathrm{Rp} 20$ milyar rupiah sampai denga 40 milyar rupiah tanpa penetapan pelaksanaan pidana denda. Kedua, Hakim menjatuhkan pidana penjara selama antara enam bulan sampai dengan enam tahun ditambah pidana denda sebesar antara 20 milyar rupiah sampai denga 40 milyar rupiah dengan ketentuan subsider apabila pidana denda tidak dibayar. Ketiga, menjatuhkan pidana penjara selama antara enam bulan sampai dengan enam tahun ditambah pidana denda sebesar antara 20 milyar rupiah sampai denga 40 milyar rupiah dengan penetapan perampasan harta terpidana dan pelelangan apabila pidana denda tidak dibayar.

Ketiga pola putusan tersebut menimbulkan konsekwensi yang berbeda terhadap eksekusi pidana denda. Pola pemidanaan pertama dan kedua memberikan konsekwensi yang sama, yaitu apabila denda tidak dibayar maka diganti dengan pidana kurungan paling sedikit satu hari dan paling lama enam bulan atau delapan bulan jika ada pemberatan. Pada pola pemidanaan ketiga, apabila denda tidak dibayar pada waktunya maka dilakukan pelelangan harta terpidana dan hasilnya digunakan sebagai pembayar pidana denda.

Dari ketiga pola pemidanaan tersebut, dapat dilihat hanya pola pemidanaan ketiga yang memberikan kemanfaatan hukum berupa penerimaan pada kas negara. Sedangkan pola pemidanaan pertama dan kedua berisiko tidak terbayarnya pidana denda.

\section{Pengaruh Ketiadaan Norma Pelaksanaan Pidana Denda dalam UU KUP Terhadap Putusan Hakim.}

Untuk mengetahui pengaruh ketiadaan norma eksekusi pidana denda dalam UU KUP terhadap putusan Hakim, penelitian ini mengambil lima belas putusan Majelis Hakim pada perkara tindak pidana di bidang perpajakan dari Direktori Putusan Mahkamah Agung. Putusan yang diambil hanya dibatasi pada tingkat putusan Pengadilan Negeri. Pola pemidanaan putusan-putusan yang diperoleh dapat dilihat pada tabel di bawah ini.

Tabel 1. Putusan Pemidanaan di Bidang Perpajakan

\begin{tabular}{|c|c|c|}
\hline No & No. \& Tanggal Putusan & Putusan Pemidanaan \\
\hline 1. & $\begin{array}{l}\text { 1468/Pid.B/2017/PN.Tjk } \\
\text { Tanggal } 8 \text { Februari } 2018\end{array}$ & Pidana penjara selama 4 tahun dan denda sebanyak Rp19.068.000.092,00. \\
\hline 2. & $\begin{array}{l}\text { 19/Pid.Sus/2017/PN Skt } \\
\text { Tanggal } 11 \text { April } 2018\end{array}$ & $\begin{array}{l}\text { Pidana penjara selama } 2 \text { tahun } 6 \text { bulan dan pidana denda kepada Terdakwa sebesar } 2 \mathrm{x} \\
\text { Rp13.272.329.461,00 = Rp26.544.658.922,00 jika terdakwa tidak membayar denda } \\
\text { tersebut paling lama waktu } 1 \text { bulan sesudah putusan ini yang telah memperoleh kekuatan } \\
\text { hukum tetap, maka harta benda terdakwa disita oleh Jaksa dan dilelang untuk membayar } \\
\text { denda dimaksud. }\end{array}$ \\
\hline 3. & $\begin{array}{l}\text { 155/Pid.B/2018/PN Bd, } \\
\text { Tanggal } 24 \text { April .2018 }\end{array}$ & $\begin{array}{l}\text { Pidana penjara selama } 2 \text { tahun } 6 \text { bulan dan pidana denda sejumlah } 2 \text { x Rp } \\
300.417 .700,00=\mathrm{Rp} 600.835 .400,00 \text { dengan ketentuan apabila denda tersebut tidak } \\
\text { dibayar maka diganti dengan pidana kurungan selama } 2 \text { (dua) bulan }\end{array}$ \\
\hline
\end{tabular}


4. 32/Pid.B/2018/PN Bdg

Tanggal 4 April 2018

5. 306/Pid.Sus/2018/PN Jkt.Utr. Tanggal 28 Mei 2018

6. 1347/Pid.Sus/2018/PN Jkt.Sel

Tanggal 30 Januari 2019

7. 170/Pid.Sus/2019/PN Sbw

Tanggal 25 September 2019

8. 702/Pid.Sus/2019/PNJkt.Utr Tanggal 5 Maret 2020

9. 8/Pid.B/2020/PN Spt

Tanggal 2 April 2020

10. 7/Pid.B/2020/PN Spt

Tanggal 2 April 2020

\section{276/Pid.Sus/2020/Pn Plg \\ Tanggal 13 Juli 2020}

12. 53/Pid.Sus/2020/PN.Jkt. Sel

Tanggal 24 Agustus 2020

13. 337/Pid.Sus/2020/PN Jkt.Sel,

Tanggal 5 Agustus 2020

14. 73/Pid.B/2020/PN Lss Tanggal 13 Oktober 2020.

15. 1161/Pid.Sus/2020/PN.Jkt.Utr Tanggal 18 November 2020

Pidana penjara selama 1 tahun 6 bulan dan denda sejumlah $2 \times$ Rp4.318.005.939,00 = Rp8.636.011.878 dengan ketentuan apabila denda tersebut tidak dibayar diganti dengan pidana kurungan selama 4 bulan.

Pidana penjara selama 2 tahun 6 bulan dan denda sejumlah $2 \times$ Rp35.088.666.435,00 = Rp70.177.332.870,00, dengan ketentuan apabila pidana denda tersebut tidak dibayar maka diganti dengan pidana kurungan selama 4 bulan.

Pidana penjara selama 2 tahun 6 bulan dan denda sebesar $2 \times$ Rp3687,870.151,00 = Rp7.375.740.302,00 subsidair 4 bulan.

Pidana penjara selama 2 tahun dan denda sebesar Rp3.234.622.545,00 dengan ketentuan jika terdakwa tidak membayar denda paling lama dalam waktu 1 bulan sesudah putusan pengadilan memperoleh ketentuan hukum tetap, maka harta bendanya dapat disita oleh Jaksa dan kemudian dilelang untuk membayar denda, dalam hal terdakwa tidak mempunyai harta benda yang mencukupi untuk membayar denda, maka terdakwa dijatuhi hukuman kurungan pengganti denda selama 3 bulan.

Pidana penjara selama 2 tahun dan denda sebesar Rp3.105.348.096,00 dengan ketentuan apabila denda tersebut tidak dibayar sesuah putusan Pengadilan memperoleh kekuatan hukum tetap, maka harta bendanya dapat disita oleh Jaksa dan kemudian akan dilelang untuk membayar denda, dalam hal terdakwa tidak mempunyai hanta benda yang mencukupi untuk membayar denda maka terdakwa dijatuhi hukuman kurungan pengganti denda selama 3 bulan.

Pidana penjara selama 3 tahun dan pidana denda sejumlah Rp8.404.570.000,00 jika terdakwa tidak membayar denda paling lama dalam waktu 1 bulan sesudah putusan Pengadilan memperoleh kekuatan hukum tetap, maka harta bendanya dapat disita oleh Jaksa Penutut Umum dan kemudian dilelang untuk membayar denda kemudian dalam hal terdakwa tidak mempunyai harta benda yang mencukupi untuk membayar denda, maka diganti dengan pidana kurungan pengganti denda selama 3 bulan.

Pidana penjara selama 2 tahun dan pidana denda sejumlah Rp648.875.960,00, dengan ketentuan apabila denda tersebut tidak dibayar paling lama 1 bulan, setelah Putusan memperoleh kekuatan hukum tetap, maka harta bendanya dapat disita oleh Jaksa Penuntut Umum dan kemudian dilelang untuk membayar denda, dalam hal Terdakwa tidak memiliki harta benda yang mencukupi untuk membayar denda tersebut, maka diganti dengan pidana kurungan selama 3 bulan.

Pidana penjara selama 1 tahun dan pidana denda sebesar Rp2.314.190.602.00 dengan ketentuan apabila pidana denda tersebut tidak dibayar, diganti dengan pidana kurungan selama 6 bulan

Menjatuhkan pidana penjara selama 1 tahun 6 bulan dan denda sebesar $2 \mathrm{x}$ Rp31.387.236.540,00 = Rp62.774.473.080,00 dengan ketentuan jika denda tidak dibayar diganti dengan kurungan selama 3 bulan.

Pidana penjara selama 5 tahun 6 bulan dan denda pajak sebesar $2 \quad \mathrm{x}$ Rp10.254.308.910,00 yaitu sebesar Rp 20.508.617.820,00, jika terdakwa tidak membayar denda tersebut, maka diganti dengan hukuman kurungan selama 6 bulan.

Pidana penjara selama 1 tahun 4 bulan serta denda sejumlah Rp.2.545.985.316,00 dengan ketentuan jika terdakwa tidak membayar denda dalam waktu paling lama 1 bulan sesudah putusan Pengadilan memperoleh kekuatan hukum tetap, maka harta bendanya dapat disita oleh Jaksa dan kemudian dilelang untuk membayar denda, dalam hal terdakwa tidak mempunyai harta benda yang mencukupi untuk membayar denda, maka terdakwa dijatuhkan hukuman kurungan pengganti denda selama 4 bulan

Pidana penjara selama 3 tahun dan denda sebesar $2 \times \mathrm{Rp} 14.111 .331 .383,00=$ Rp28.222.662.766,00, dengan ketentuan apabila terdakwa tidak membayar denda tersebut paling lama waktu 1 bulan setelah putusan telah memperoleh kekuatan hukum tetap maka harta benda milik terdakwa dapat disita oleh Jaksa dan dilelang untuk membayar denda, dalam hal terdakwa tidak mempunyai harta benda yang mencukupi untuk membayar denda maka terdakwa dijatuhi hukuman pengganti denda selama 6 bulan kurungan

Sumber: Direktori Putusan Mahkamah Agung. ${ }^{8}$

Dari putusan-putusan tersebut dapat diketahui terdapat tiga pola pemidanaan sebagai berikut:

a. Satu putusan menjatuhkan pidana penjara dan pidana denda tanpa penetapan pelaksanaan pidana denda. Putusan tersebut terdapat pada Putusan Nomor: 1468/Pid.B/2017/PN.Tjk.

${ }^{8}$ Mahkamah Agung Republik Indonesia, Direktori Putusan, https://putusan3. mahkamahagung.go.id/direktori/ index/kategori /perpajakan-1.html, diakses 28-30 Desember 2020. 
b. Tujuh putusan menjatuhkan pidana penjara dan pidana denda dengan subsider kurungan apabila denda tidak dibayar. Putusan tersebut terdapat pada Putusan Nomor: 155/Pid.B/2018/PN Bd, 32/Pid.B/2018/PN Bdg, 306/Pid.Sus/2018/ PN Jkt.Utr, 1347/Pid.Sus/2018/PN Jkt.Sel, 276/Pid.Sus/ 2020/Pn Plg, 53/Pid.Sus/2020/PN.Jkt.Sel 2020, dan 337/Pid.Sus/2020/PN Jkt.Sel.

c. Tujuh putusan menjatuhkan pidana penjara dan pidana dengan ketentuan apabila denda tidak dibayar dalam waktu 1 (satu) bulan sesudah putusan pengadilan memperoleh kekuatan hukum tetap, maka harta bendanya dapat disita dan kemudian dilelang untuk membayar denda. Putusan tersebut terdapat pada Putusan Nomor: 19/Pid.Sus/2017/PN Skt, 170/ Pid.Sus/2019/PN Sbw, 702/Pid.Sus/2019/ PNJkt.Utr, 8/Pid.B/2020/PN Spt, 7/Pid.B/2020/PN Spt, 73/Pid.B/2020/PN Lss, dan 1161/Pid.Sus/2020/PN.Jkt.Utr.

Sebagaimana telah diuraikan sebelumnya, putusan pidana denda tanpa penetapan pelaksanaan pidana denda (kelompok putusan huruf a) dan putusan pidana denda dengan subsider (kelompok putusan huruf b) akan berakibat sama, yaitu apabila denda tidak dibayar maka diganti dengan pidana kurungan. Pilihan kurungan pengganti yang relatif singkat lebih menguntungkan dari pada membayar pidana denda yang besar dapat dimanfaatkan sebagai pilihan oleh terpidana. Sebagai contoh, pada Putusan Nomor 53/Pid.Sus/2020/PN.Jkt.Sel, terdakwa dijatuhi pidana denda sebesar Rp62.774.473.080,00 dengan ketentuan jika denda tidak dibayar diganti dengan kurungan selama tiga bulan. Contoh lain pada Putusan Nomor 306/Pid.Sus/2018/PN Jkt.Utr, terdakwa dijatuhi pidana denda sebesar Rp70.177.332.870,00 dengan ketentuan apabila pidana denda tersebut tidak dibayar maka diganti dengan pidana kurungan selama empat bulan.

Putusan tersebut akan mencederai rasa keadilan dan menghilangkan kemanfaatan hukum. Sebagai sumber pendapatan negara, pajak berfungsi untuk membiayai pengeluaran-pengeluaran negara. Untuk menjalankan tugastugas rutin dan melaksanakan pembangunan, negara membutuhkan biaya. Biaya ini dapat diperoleh dari penerimaan pajak. ${ }^{9}$ Pemidanaan berupa denda akan lebih bermanfaat bagi negara dibanding dengan pidana kurungan. Begitu juga dengan rasa keadilan, adilkah kerugian negara yang jumlahnya puluhan milyar rupiah bahkan bisa mencapai triliun rupiah ${ }^{10}$ hanya disubsider dengan kurungan enam samapai delapan bulan. Kepastian dibayarnya pidana denda oleh terpidana hanya dilakukan dengan penetapan sita harta benda dan pelelangan apabila denda tidak dibayar sebagaimana pada pola kelompok putusan huruf c.

Inkonsisten putusan Hakim atas pelaksanaan pembayaran denda terjadi akibat tidak diaturnya norma pelaksanaan pidana denda secara khusus dalam UU KUP. Dengan tidak diaturnya norma pelaksanaan pidana denda, maka Hakim memiliki ruang diskresi ketika menjatuhkan pemidanaan. Hakim memiliki kewenangan yudisial independen (judicial independence) yang diatur dalam Undang-Undang Nomor 48 Tahun 2009 tentang Kekuasan Kehakiman sekaligus menjadi pedoman Hakim dalam menjalankan tugas dan wewenangnya dalam mengadili perkara-perkara pidana. Hakim di Indonesia tidak terikat dengan yurisprudensi putusan sebelumnya. Oleh karena itu ketidakseragaman dalam putusan sangat lazim terjadi.

\section{Mekanisme Pemulihan Kerugian Keuangan Negara Akibat Tindak Pidana di Bidang Perpajakan Sebelum dan Setelah UU Cipta Kerja}

Dari uraian sebelumnya dapat diketahui bahwa terdapat risiko pidana denda yang tidak dibayar oleh terpidana. UU KUP seolah lebih mengedepankan pembalasan berupa pidana penjara dan/atau kurungan. Padahal, perbuatan pidana di bidang perpajakan mengakibatkan kerugian pada pendapatan Negara. Kerugian pada pendapatan Negara adalah jumlah pajak yang tidak/atau kurang dibayar akibat perbuatan pidana yang dilakukan oleh terpidana. Keadaan ini menimbulkan pertanyaan mengenai kemanfaatan hukum pidana apabila hanya bertujuan memenjarakan pelaku, sementara negara kehilangan haknya atas uang pajak. Adakah upaya hukum yang dapat dilakukan Dirjen Pajak untuk memulihkan kerugian keuangan negara?

Menurut Soemitro sanksi pidana merupakan hukuman bagi perbuatannya. Sanksi pidana termasuk wewenang pengadilan pidana, dan penetapan pajak merupakan wewenang Dirjen Pajak, dua instansi yang berlainan, instansi yang satu tidak dapat memasuki wewenang instansi lainnya. ${ }^{11}$ Sanksi pidana penjara dan pidana denda yang dihitung berdasarkan jumlah pajak terutang yang tidak/atau kurang dibayar ditujukan kepada pelaku atas perbuatannya. Sanksi pidana denda bukanlah pembayaran pajak terutang. Utang pajak yang timbul akibat perbuatan pidana tidak hilang walau telah dijatuhkan sanksi pidana dan tetap harus dibayar oleh Wajib Pajak.

Secara hukum positif, kewenangan Dirjen Pajak untuk menetapakan jumlah pajak terutang yang tidak/atau kurang dibayar akibat terjadinya tindak pidana di bidang perpajakan dituangkan pada Pasal 13 ayat (5) dan Pasal 15 ayat (4) UU KUP sebagai berikut:

${ }_{9}^{9}$ Direktorat Jenderal Pajak, Fungsi Pajak, https://www.pajak.go.id/id/fungsi-pajak\#, diakses 5 Januari 2021

${ }^{10}$ Pada kasus Asian Agri Group kerugian pada pendapatan negara terbukti mencapai Rp1.259.977.695.652,00, Lihat Putusan Mahkamah Agung Nomor 2239 K/PID.SUS/2012.

${ }^{11}$ Rochmat Soemitro, Asas dan Dasar Perpajakan 3, (Bandung:Eresco, 1990), hlm. 35. 
Pasal 13 ayat (5)

Walaupun jangka waktu 5 (lima) tahun sebagaimana dimaksud pada ayat (1) telah lewat, Surat Ketetapan Pajak Kurang Bayar tetap dapat diterbitkan ditambah sanksi administrasi berupa bunga sebesar 48\% (empat puluh delapan persen) dari jumlah pajak yang tidak atau kurang dibayar, apabila Wajib Pajak setelah jangka waktu tersebut dipidana karena melakukan tindak pidana di bidang perpajakan atau tindak pidana lainnya yang dapat menimbulkan kerugian pada pendapatan negara berdasarkan putusan pengadilan yang telah mempunyai kekuatan hukum tetap.

Pasal 15 ayat (4):

Apabila jangka waktu 5 (lima) tahun sebagaimana dimaksud pada ayat (1) telah lewat, Surat Ketetapan Pajak Kurang Bayar Tambahan tetap dapat diterbitkan ditambah sanksi administrasi berupa bunga sebesar 48\% (empat puluh delapan persen) dari jumlah pajak yang tidak atau kurang dibayar, dalam hal Wajib Pajak setelah jangka waktu 5 (lima) tahun tersebut dipidana karena melakukan tindak pidana di bidang perpajakan atau tindak pidana lainnya yang dapat menimbulkan kerugian pada pendapatan negara berdasarkan putusan pengadilan yang telah mempunyai kekuatan hukum tetap.

Penjelasan Pasal 13 ayat (5) menguraikan bahwa dalam rangka memperoleh kembali pajak yang terutang tersebut, dalam hal Wajib Pajak dipidana karena melakukan tindak pidana di bidang perpajakan atau tindak pidana lainnya yang dapat menimbulkan kerugian pada pendapatan negara berdasarkan putusan Pengadilan yang telah mempunyai kekuatan hukum tetap, Surat Ketetapan Pajak Kurang Bayar masih dibenarkan untuk diterbitkan, ditambah sanksi administrasi berupa bunga sebesar 48\% (empat puluh delapan persen) dari jumlah pajak yang tidak atau kurang dibayar meskipun jangka waktu 5 (lima) tahun sebagaimana dimaksud pada ayat (1) dilampaui. Demikian pula dalam penjelasan Pasal 15 ayat (4) dijelaskan bahwa Surat Ketetapan Pajak Kurang Bayar Tambahan tetap dapat diterbitkan, ditambah sanksi administrasi berupa bunga sebesar 48\% (empat puluh delapan persen) dari jumlah pajak yang tidak atau kurang dibayar meskipun jangka waktu 5 (lima) tahun sebagaimana dimaksud pada ayat (1) dilampaui.

Dari ketentuan-ketentuan di atas, dapat dilihat bahwa pemulihan kerugian keuangan negara akibat perbuatan pidana di bidang perpajakan dilakukan secara administrasi dengan menerbitkan Surat Ketetapan Pajak yang nantinya ditindaklanjuti dengan proses penagihan. Apabila pidana denda tidak dibayar, kerugian negara tetap terpulihkan melalui proses administrasi perpajakan.

Setahun sebelum diundangkannya UU Cipta Kerja, penerapan Pasal Pasal 13 (5) dan Pasal 15 ayat (4) telah dibatalkan oleh Surat Edaran Mahkamah Agung (SEMA) Nomor 2 Tahun 2019 tanggal 27 November 2019. SEMA tersebut memberikan pedoman dalam penanganan perkara di Mahkamah Agung, pengadilan tingkat pertama, dan pengadilan tingkat banding. Dalam rumusan pleno kamar tata usaha negara, dirumuskan mengenai penerbitan Surat Ketetapan Pajak Kurang Bayar (SKPKB) setelah putusan pidana sebagai berikut:

Upaya penegakan hukum di luar pengadilan ataupun upaya-upaya litigasi penegakan hukurn perpajakan dalam rangka menyelesaikan suatu sengketa perpajakan termasuk dalam lingkungan peradilan administrasi ataupun pengadilan pajak seharusnya dilakukan sebelum dilakukannya tindakan-tindakan hukurn pidana perpajakan (ultimum remedium).

Apabila suatu permasalahan perpajakan telah diadili dan diputus oleh suatu putusan Hakim pidana yang berkekuatan hukum tetap, maka tidak dibenarkan lagi melakukan tindakan-tindakan penegakan hukum lain baik di luar ataupun di depan pengadilan karena putusan Hakim pidana dalam tindak pidana perpajakan adalah mengakhiri suatu upaya penegakan hukum (litis finiri oportet), dan asas yang berlaku adalah asas ultimum remedium".

Penghapusan Pasal 13 (5) dan Pasal 15 ayat (4) UU KUP oleh UU Cipta Kerja menghilangkan keraguan penerapan SEMA Nomor 2 Tahun 2019. Secara legalitas (lex scripta) ketentuan Pasal 13 (5) dan Pasal 15 ayat (4) UU KUP menjadi sah tidak berlaku. Sebagai konsekwensinya Dirjen Pajak kehilangan kewenangan untuk menetapkan dan menagih utang pajak yang timbul akibat perbuatan pidana. Penghapusan dua pasal ini akan mengakibatkan terpidana di bidang perpajakan tidak membayar apapun, baik sanksi pidana denda maupun pokok utang pajak yang tidak/atau kurang dibayar apabila Hakim tidak menetapkan penyitaan harta terpidana dalam putusannya. Penegakan hukum pidana di bidang perpajakan justru dapat mengakibatkan tidak ada uang yang masuk ke kas negara baik dari pidana denda maupun dari pajak terutang yang digelapkan.

Konsekwensi lainnya adalah Wajib Pajak kemungkinan besar tidak akan menggunakan haknya untuk mengungkapkan ketidakbenaran perbuatan dengan membayar pokok pajak ditambah sanksi $100 \%$ pada saat proses Pemeriksaan Bukti Permulaan sebagaimana diatur Pasal 8 ayat (4) dan penghentian penyidikan untuk kepentingan 
negara dengan membayar pokok pajak ditambah sanksi sebesar 300\% sebagaimana diatur dalam Pasal 44B UU KUP yang telah diubah dengan UU Cipta Kerja. Hukuman pidana penjara yang singkat dianggap lebih menguntungkan dari pada harus membayar utang pajak dan sanksi administrasi yang besar.

Menurut Barda Nawawi Arief, kebijakan atau upaya penanggulangan kejahatan pada hakikatnya merupakan bagian integral dari upaya perlindungan masyarakat (social defence) dan upaya mencapai kesejahteraan masyarakat (social welfare). Oleh karena itu, dapat dikatakan bahwa tujuan akhir atau tujuan utama dari politik kriminal ialah perlindungan masyarakat untuk mencapai kesejahteraan masyarakat. ${ }^{12}$ Pada hakikatnya korban dari kejahatan di bidang perpajakan adalah masyarakat. Masyarakat kehilangan haknya untuk sejahtera memalalui pemanfaatan dana pajak. Kebijakan penghapusan Pasal 13 ayat (5) dan Pasal 15 ayat (4) UU KUP dalam UU Cipta Kerja mengandung risiko bahwa negara kehilangan hak atas pajak. Dilain pihak, memenjarakan Wajib pajak menimbulkan tambahan biaya lapas yang menjadi beban APBN dan berdampak mengurangi penerimaan pajak. ${ }^{13}$

\section{Urgensi Regulasi Eksekusi Pidana Denda di Bidang Perpajakan}

Dari pembahasan sebelumnya, terlihat bahwa penegakan hukum pidana di bidang perpajakan pasca UU Cipta Kerja menjadi lebih bersifat retibutif dengan pemenjaraan pelaku. Kemanfaatan hukum pidana menjadi terabaikan. Hukum pidana seharusnya dapat digunakan untuk mendukung fungsi pajak sebagai alat untuk mengisi kas negara.

Menurut Sudarto penggunaan hukum pidana harus memerhatikan tujuan pembangunan nasional, yaitu mewujudkan masyarakat adil dan makmur yang merata materiil spiritual berdasarkan Pancasila. Sehubungan dengan ini maka penggunaan hukum pidana bertujuan untuk menanggulangi kejahatan dan mengadakan pengugeran terhadap tindakan penanggulangan itu sendiri, demi kesejahteraan dan pengayoman masyarakat. Penggunaan hukum pidana harus pula memperhitungkan prinsip biaya dan hasil (cost and benefit principle). ${ }^{14}$ Pemenjaraan akan menimbulkan biaya bagi negera, hal ini menjadi kontradiksi yang mana pajak seharusnya merupakan penghasilan bagi negara. Dilihat dari sisi penerimaan negara, penegakan hukum pidana sebagai upaya ultimum remedium justru menjadi kurang bermanfaat dibandingkan penegakan hukum administrasi di bidang perpajakan.

Alasan adanya ketentuan pidana dalam Perpajakan menurut Gunadi antara lain mencapai kecukupan penerimaan dalam penyelenggaraan pemerintah dan pembangunan guna mensejahterakan rakyat, mencapai dan memelihara ekualitas pemajakan kepada semua subjek yang seharusnya berkewajiban membayar pajak, serta sekaligus menjaga keadilan pajak, terutama melindungi WP Patuh sehingga tidak terjadi degradasi kepatuhan. ${ }^{15}$ Pemidanaan di bidang perpajakan tanpa mempertimbangkan penerimaan negara akan menghambat kecukupan penerimaan negara serta bertentangan dengan keadilan ekualitas pemajakan karena pemidanaan justru memungkinkan pelaku bebas dari kewajiban membayar pajak.

Di Belanda, pelanggaran-pelanggaran fiskal atau pajak (Pasal 4 ayat (3) sub c, Pasal 4 dan Pasal 5 Inveringsverordeningg Strafwetboek dan KB yang diundangkan dalam Ind. Stbl. 1923 Nomor 394, Hakim tidak menetapkan pidana kurungan pengganti, akan tetapi Hakim menetapkan waktu selama yang dipidana denda dapat ditahan dalam gijzeling karena tidak membayar dendanya. Perbedaan prispil antara penyanderaaan dan pidana kurungan pengganti adalah penyanderaan itu tidak bersifat mengganti. Mengadakan penyanderaan tidak berarti kehilangan hak untuk membebani denda yang bersangkutan pada kekayaan dari yang dipidana denda. Bahkan, hak tersebut dapat juga dibebani pada barang-barang yang kemudian menjadi kekayaan dari yang dipidana denda. ${ }^{16}$ Dari ketentuan tersebut terlihat negara Belanda mengedepankan pemulihan kerugian keuangan negara dalam penanganan pidana perpajakan.

Sehubungan dengan manfaat, keuntungan, dan rasa keadilan tentang penerapan pidana denda, Sutherland dan Cressey memandang bahwa pidana denda adalah jenis hukuman yang menguntuhgkan pemerintah, karena pemerintah tidak banyak mengeluarkan biaya, bila tanpa disertai dengan kerugian subsidair. Hukuman denda tidak membawa atau tidak mengakibatkan tercelanya nama baik atau kehormatan seperti yang dialami terpidana. Pidana denda akan membuat lega dunia perikemanusiaan. Hukuman denda akan menjadi penghasilan bagi daerah/kota. ${ }^{17}$

Untuk mengembalikan tujuan kemanfaatan penggunaan hukum pidana di bidang perpajakan, maka menjadi kebutuhan yang mendesak untuk menyusun regulasi eksekusi pidana denda di bidang perpajakan. Menyerahkan pelaksanaan pidana denda di bidang perpajakan pada norma umum dalam KUHP dan KUHAP belum dapat

12 Barda Nawawi Arief, Bunga Rampai Kebijakan Hukum Pidana, Perkembangan Penyusunan Konsep KUHP Baru, Cetakan ke-6, (Jakarta:Kencana, 2017), hlm. 2

${ }^{13}$ A. Anshari Ritonga, Ultimum Remedium dalam Sanksi Pidana Pajak, (Yogyakarta: FH UGM, 2018), hlm. 5.

${ }^{14}$ Barda Nawawi Arief, Op.Cit, hlm. 31.

${ }^{15}$ Gunadi, Op.Cit.

${ }^{16}$ Rico Aldiyanto Batuwael, dkk, "Fungsi Pidana Denda dalam Sistem Pemidanaan di Indonesia", Lex Crimen, Vol. IX, no. 3, (Jul-Sep 2020):33.

${ }^{17}$ Syaiful Bakhri, "Penggunaan Pidana Denda dalam Perundang-undangan", Jurnal Hukum, Vol. 9, no. 21, (September 2002):49. 
menyelesaikan masalah kemanfaatan penggunaan hukum pidana dalam perpajakan. Oleh karena itu, pertimbangan utama merumuskan pelaksanaan pidana denda adalah tujuan manfaat hukum untuk mewujutkan fungsi pajak sebagai sumber pembiayaan terbesar negara dengan tidak mengabaikan tujuan keadilan dan kepastian hukum.

Muladi dan Barda Nawawi Arief mengemukakan bahwa dalam pelaksanaan pidana denda perlu dipertimbangkan antara lain: sistem penetapan jumlah atau besarnya pidana denda, batas waktu pelaksanaan pidana denda, tindak-tindakan paksa yang diharapkan dapat menjamin terlaksananya pembayaran denda dalam hal terpidana tidak membayar dalam batas waktu yang ditetapkan. ${ }^{18}$ Dari pendapat tersebut, rumusan norma eksekusi pidana denda di bidang perpajakan setidak-tidaknya memuat ketentuan-ketentuan mengenai jangka waktu pembayaran pidana denda, kewenangan jaksa eksekutor untuk merampas dan menjual harta kekayaan milik terpidana apabila pidana denda tidak dibayar pada batas waktu yang ditentukan. Hukuman kurungan pengganti hanya ditetapkan apabila hasil penjualan harta kekayaan milik terdakwa tidak mencukupi nilai kerugian keuangan negara.

Rumusan pelaksanaan pidana denda pada Pasal 273 KUHAP dapat digunakan sebagai acuan perumusan norma eksekusi pidana denda di bidang perpajakan dengan melakukan penyesuaian. Setidak-tidaknya rumusan mengatur:jangka waktu paling lambat pidana denda dibayar, kewenangan jaksa eksekutor untuk menyita dan melelang harta benda milik terpidana apabila sampai dengan jangka waktu yang ditentukan tidak dibayar, dan penggantian (subsider) pidana denda dengan pidana kurungan hanya diterapkan apabila hasil penjualan harta kekayaan yang dirampas tidak mencukupi untuk pembayaran pidana denda yang ditetapkan

Formulasi eksekusi pidana denda yang sejalan dengan rumusan di atas sebenarnya dapat ditemukan pada pidana khusus lainnya, antara lain pada tindak pidana pencucian uang (TPPU). Pelaksanaan pidana denda terhadap Korporasi yang terbukti melakukan TPPU dirumuskan dalam Pasal 9 UU TPPU sebagai berikut:

(1) Dalam hal Korporasi tidak mampu membayar pidana denda sebagaimana dimaksud dalam Pasal 7 ayat (1), pidana denda tersebut diganti dengan perampasan Harta Kekayaan milik Korporasi atau Personil Pengendali Korporasi yang nilainya sama dengan putusan pidana denda yang dijatuhkan.

(2) Dalam hal penjualan Harta Kekayaan milik Korporasi yang dirampas sebagaimana dimaksud pada ayat (1) tidak mencukupi, pidana kurungan pengganti denda dijatuhkan terhadap Personil Pengendali Korporasi dengan memperhitungkan denda yang telah dibayar.

Dengan rumusan eksekusi pidana denda yang memenuhi unsur-unsur di atas akan lebih menjamin terpulihkannya kerugian negara walaupun masih ada kemungkinan tidak seluruhnya terpulihkan karena ketidakcukupan dari harta yang disita. Dengan demikian hukum pidana telah memainkan perannya dengan memberi manfaat kepada kesejahteraan masyarakat. Dari sisi kewajiban membayar pajak, jaminan pembayaran pidana denda memberikan rasa keadilan dengan memelihara ekualitas pemajakan kepada semua subjek yang seharusnya berkewajiban membayar pajak, terutama bagi subjek pajak yang patuh.

Untuk terciptanya kepastian hukum, idealnya rumusan norma eksekusi pidana denda dimuat pada ketentuan pidana dalam UU KUP. Dalam Rancangan Undang-Undang Ketentuan Umum dan Tata Cara Perpajakan (RUU KUP $)^{19}$ telah dimuat norma eksekusi pidana denda. ${ }^{20}$ Namun untuk mensahkan RUU KUP menjadi UU KUP baru tentu memerlukan waktu yang lama sementara UU Cipta Kerja telah diberlakukan.

Untuk mengatasi urgensi kebutuhan akan norma eksekusi pidana denda, dapat dilakukan oleh Mahkamah Agung dengan menerbitkan Surat Edaran Mahkamah Agung (SEMA). Sebagaimana diatur pada Pasal 32 ayat (4) Undang-Undang Nomor 14 Tahun 1985 tentang Mahkamah Agung sebagaimana telah diubah terakhir dengan Undang-Undang Nomor 3 Tahun 2009 (UU MA) yang berbunyi: "Mahkamah Agung berwenang memberi petunjuk, teguran, atau peringatan yang dipandang perlu kepada pengadilan di semua lingkungan peradilan." Kemudian berdasarkan Pasal 79 UU MA, Mahkamah Agung berwenang untuk mengatur hal-hal demi kelancaran penyelenggaran peradilan apabila terdapat hal-hal yang belum jelas diatur dalam undang-undang.

Peraturan yang disusun oleh Mahkamah Agung dalam bentuk SEMA hanya dimaksudkan untuk penyelenggaraan peradilan dan merupakan bagian dari hukum acara secara keseluruhan. Dengan demikian, SEMA dapat dikeluarkan oleh Mahkamah Agung dengan tidak mencampuri dan melampaui pengaturan tentang hak dan kewajiban warga negara pada umumnya, tidak pula mengatur sifat, kekuatan, alat pembuktian serta penilaian pembuktian. ${ }^{21}$

${ }^{18}$ Meli Indah Sari dan Hafrida, "Penerapan Pidana Penjara Sebagai Pengganti Pidana Denda dalam Putusan Perkara Tindak Pidana Narkotika", Pampas: Journal of Criminal Law, Vol. 1, no. 1, (Februari, 2020):49

${ }^{19}$ RUU KUP telah diusulkan dalam Program Legislasi Nasional pada tanggal 2 Februari 2015, namun sampai dengan hari ini belum juga disahkan sebagai Undang-Undang

${ }^{20}$ Lihat Pasal 116, Pasal 117, Pasal 119 dan Pasal 120 RUU KUP

21 Ari Iswahyuni, "Kedudukan Ancaman Pidana Minimal Dalam Undang-Undang Nomor 35 Tahun 2009 Tentang Narkotika Pasca Dikeluarkannya Surat Edaran Mahkamah Agung Nomor 3 Tahun 2015”. Jurnal Panorama Hukum, Vol.3, no.1, (Juni 2018):30. 
Berdasarkan kewenangan dan kemudahan penerbitan SEMA tersebut, maka Mahkamah Agung dapat menerbitkan SEMA yang berisi petunjuk kepada Hakim di semua lingkungan peradilan mengenai pedoman pemidanaan dengan mewajibkan penetapan batas waktu pembayaran pidana denda serta perampasan dan pelelangan barang bukti sebagaimana diatur pada Pasal 273 KUHAP dalam putusan Hakim. Dengan demikian SEMA tersebut dapat menjaga konsistensi putusan dan lebih menjamin terpulihkannya kerugian keuangan negara tanpa membuat norma baru yang bertentangan dengan undang-undang.

\section{SIMPULAN}

UU KUP tidak merumuskan norma eksekusi pidana denda secara khusus. Akibat tidak diatur secara khusus, dalam praktik peradilan terjadi inkonsisten dalam pola putusan Hakim. Terdapat tiga pola putusan pidana denda. Pertama, pidana denda tanpa diikuti penetapan eksekusi pidana denda. Kedua, pidana denda dengan subsider kurungan apabila denda tidak dibayar. Ketiga, pidana dengan ketentuan apabila denda tidak dibayar dalam jangka waktu tertentu sesudah putusan Pengadilan memperoleh kekuatan hukum tetap, maka harta bendanya dapat disita dan kemudian dilelang untuk membayar denda. Pola putusan pertama dan kedua dapat mengakibatkan pidana denda tidak dibayar oleh terpidana.

Walaupun pemidanaan terdapat risiko tidak terbayarnya denda, akan tetapi upaya pemulihan kerugian akibat perbuatan pidana di bidang perpajakan masih dapat dilakukan. Pemulihan kerugian pada pendapatan negara dilakukan dengan menerbitkan Surat Ketetapan Pajak Kurang Bayar (SKPKB) atau Surat Ketetapan Pajak Kurang Bayar Tambahan (SKPKBT) sebagai mana diatur pada Pasal 13 ayat (5) dan Pasal 15 ayat (4) UU KUP. SKPKB dan SKPKBT menjadi dasar penagihan pajak yang terutang akibat perbuatan pidana yang telah berkekuatan hukum tetap.

UU Cipta Kerja telah menghapus ketentuan Pasal 13 ayat (5) dan Pasal 15 ayat (4) UU KUP, konsekwensinya Dirjen Pajak kehilangan kewenangan untuk menetapkan dan menagih utang pajak yang timbul akibat perbuatan pidana. Dengan hilangnya kewenangan Dirjen Pajak tersebut dapat berakibat pemidanaan di bidang perpajakan tidak tidak memberikan manfaat terpulihkannya kerugian keuangan negara, baik dari uang pidana denda maupun dari penagihan utang pajak yang timbul akibat perbuatan pidana di bidang perpajakan.

Oleh karena itu, diperlukan regulasi eksekusi pidana denda perpajakan yang dapat memulihkan kerugian keuangan negara akibat tindak pidana di bidang perpajakan. Rumusan norma pelaksanaan pidana denda di bidang perpajakan setidak-tidaknya memuat ketentuan-ketentuan mengenai jangka waktu pembayaran pidana denda, kewenangan jaksa eksekutor untuk merampas dan menjual harta kekayaan milik terpidana apabila pidana denda tidak dibayar pada batas waktu yang ditentukan, Subsider hanya ditetapkan apabila hasil penjualan harta kekayaan milik terdakwa tidak mencukupi nilai kerugian keuangan negara.

Regulasi dapat dilakukan dengan bentuk rumusan norma positif yang dimuat dalam UU KUP. Akan tetapi, perubahan undang-undang memerlukan waktu yang lama. Untuk mengatasi urgensi kebutuhan regulasi tersebut, alternatif yang dapat dilakukan adalah dengan menerbitkan Surat Edaran Mahkamah Agung (SEMA). SEMA berisi petunjuk kepada Hakim di semua lingkungan peradilan mengenai pedoman pemidanaan dengan mewajibkan penetapan batas waktu pembayaran pidana denda serta perampasan dan pelelangan barang bukti sebagaimana diatur pada Pasal 273 KUHAP.

\section{DAFTAR PUSTAKA}

\section{Buku}

Arief, Barda Nawawi, Bunga Rampai Kebijakan Hukum Pidana, Perkembangan Penyusunan Konsep KUHP Baru, Cetakan ke-6, Jakarta: Kencana, 2017.

Gunadi, Panduan Komprehensif Ketentuan Umum Perpajakan (KUP), Edisi Revisi, Jakarta:Bee Media Indonesia, 2016.

Hamzah, Andi, Asas-Asas Hukum Pidana, Jakarta:Rineka Cipta, 2010.

Manan, Bagir, Sistem Peradilan Berwibawa Suatu Pencarian, Yogyakarta:FH UII Press, 2005.

Muladi, Lembaga Pidana Bersyarat, Bandung: Penerbit Alumni, 2002.

Soemitro, Rochmat, Asas dan Dasar Perpajakan 3, Bandung:Eresco, 1990.

\section{Jurnal}

Bakhri, Syaiful, "Penggunaan Pidana Denda dalam Perundang-undangan", Jurnal Hukum, Vol. 9, no. 21, (September 2002):49.

Batuwael, Rico Aldiyanto, dkk., "Fungsi Pidana Denda dalam Sistem Pemidanaan di Indonesia", Lex Crimen, Vol. IX, no. 3, (Jul-Sep 2020):33.

Iswahyuni, Ari, "Kedudukan Ancaman Pidana Minimal Dalam Undang-Undang Nomor 35 Tahun 2009 Tentang Narkotika Pasca Dikeluarkannya Surat Edaran Mahkamah Agung Nomor 3 Tahun 2015". Jurnal Panorama Hukum, Vol.3, no.1, (Juni 2018):30. 
Sari, Meli Indah dan Hafrida, "Penerapan Pidana Penjara Sebagai Pengganti Pidana Denda dalam Putusan Perkara Tindak Pidana Narkotika", Pampas: Journal of Criminal Law, Vol. 1, no. 1, (Februari, 2020):49

\section{Makalah}

Ritonga, A. Anshari, Ultimum Remedium dalam Sanksi Pidana Pajak. Yogyakarta: FH UGM, 2018.

\section{Peraturan Perundang-undangan}

Indonesia, Kitab Undang-Undang Hukum Pidana.

Indonesia, Undang-Undang Republik Indonesia tentang Kitab Undang-Undang Hukum Acara Pidana, UU No. 8 Tahun 1981, LN No. 76 Tahun 1981, TLN No. 3209.

Indonesia, Undang-Undang Republik Indonesia tentang Perubahan Keempat Undang-Undang Nomor 6 tahun 1983 tentang Ketentuan Umum Dan Tata Cara Perpajakan, UU No. 16 tahun 2009, LN No. 62 Tahun 2009, TLN No. 4953.

Indonesia, Undang-Undang Republik Indonesia tentang Perubahan Kedua atas Undang-Undang Nomor 14 tahun 1985 tentang Mahkamah Agung, UU No. 3 tahun 2009, LN No. 3 Tahun 2009, TLN No. 4958.

Indonesia, Undang-Undang Republik Indonesia tentang Cipta Kerja, UU No. 11 Tahun 2020, LN No. 245 Tahun 2020, TLN No. 6573

Indonesia, Indonesia, Rancangan Undang-Undang Ketentuan Umum dan Tata Cara Perpajakan.

Mahkamah Agung Republik Indonesia, Surat Edaran Mahkamah Agung Nomor 2 Tahun 2019 tanggal 27 November 2019.

Kementerian Keuangan Republik Indonesia, Peraturan Menteri Keuangan Nomor 239/PMK.03/2014 Tentang Tata Cara Pemeriksaan Bukti Permulaan Tindak Pidana di Bidang Perpajakan tanggal 22 Desember 2014.

\section{Website/Internet}

Direktorat Jenderal Pajak, https://www.pajak.go.id/id/fungsi-pajak\#

Kementerian Keuangan Republik Indonesia, https://www.kemenkeu.go.id/dataapbn

Mahkamah Agung Republik Indonesia, Direktori Putusan, https://putusan3. mahkamahagung.go.id/direktori/ index/kategori/perpajakan-1.html 